Georgia State University

ScholarWorks @ Georgia State University

\title{
The Jewish Settlements in the West Bank: International Law and Israeli Jurisprudence
}

\author{
Michael Galchinsky \\ Georgia State University, mgalchinsky@gsu.edu
}

Follow this and additional works at: https://scholarworks.gsu.edu/english_facpub

Part of the International Law Commons, and the International Relations Commons

\section{Recommended Citation}

Galchinsky, M. (2004). The Jewish settlements in the West Bank: International law and Israeli jurisprudence. Israel Studies, 9(3), 115-136. 
Michael Galchinsky

\section{The Jewish Settlements in the West Bank: International Law and Israeli Jurisprudence}

\section{$\mathrm{M}$}

ANY Who CARE about IsRael have learned to stop caring about international law. After all, for forty years, Arab states, members of the Non-Aligned Movement and the former Soviet Union, have ceaselessly and atrociously manipulated international law so as to turn Israel into a pariah state among the nations. The UN's infamous resolutions equating Zionism with racism are only the best known examples. ${ }^{1}$ Each spring, when the UN Commission on Human Rights rolls out its allegations of Israeli human rights violations, this political body holds Israel to a far higher standard than it does states that have demonstrated far less commitment to the Geneva Conventions and the UN Charter. ${ }^{2}$ For good reasons, many who love Israel have honed their contempt for international law. ${ }^{3}$

It can be hard to remember how much energy and optimism Jewish leaders invested in the development of international law in the two decades immediately following the Shoah. Those leaders recalled all too well what had happened when the first international legal system, the League of Nations, had disintegrated and left Nazi Germany without check, to treat its citizens in its own way. Now, it is hard to remember that it was the American Jewish Committee that convinced the states' representatives at the San Francisco Conference in 1945 that human rights should become one of the pillars of the UN's mission. Or that it was René Cassin, president of the Alliance Israélite Universelle, who drafted the UN Universal Declaration of Human Rights. Or that a Polish Jew, Raphael Lemkin, coined the term "genocide" and pushed through the UN Genocide Convention. Or that two generations of American Jewish leaders saw international law as one of the cornerstones of their Never Forget/Never Again program, consistent with core Jewish values like tikkun olam, ger lo tilhaz, b'tselem elohim, kevod haberiyyoth, mippene darkhe shalom, and ben adam l'havero. 
For most of these leaders, support for internationalism in no way conflicted with their support for Jewish nationalism. They saw the Universal Declaration of Human Rights and the State of Israel as the twin births of 1948 - both dedicated to making Jews safe from persecution. ${ }^{4}$

If Israelis and their allies in the Diaspora have, since 1967, largely given up on international law, however, the rest of the world has not. The success of the ad hoc International Criminal Tribunal for the former Yugoslavia led, in 2002, to the establishment of a permanent International Criminal Court with jurisdiction over genocide, crimes against humanity, and war crimes. Even without American ratification of the ICC statute, international criminal law is arguably stronger now than at any time since the Nuremberg Tribunal.

Remembering Jews' historical commitment to international justice, we can only observe with grave concern the extent to which Israeli and international law have gradually gone their separate ways over the proper approach to the occupation of the West Bank and Gaza. In particular, the issue of the settlements has raised the conflict between the two legal systems to its highest pitch. The tension has grown so acute that, if it is not alleviated soon, it may have severe consequences for Israel's future peace and security.

\section{INTERNATIONAL LAW}

Before comparing the approaches adopted by the two legal systems, it is necessary to establish briefly the history and current scope of the settlements. Since 1967, successive Israeli governments have, directly or indirectly, participated in the transfer of some 230,000 civilians into I45 West Bank and Gaza settlements and approximately IIo outposts. ${ }^{5}$ Israeli civilian settlement in the territories began as a response of the Eshkol government to political pressure to re-settle the Gush Etzion villages and to establish a permanent presence in the Golan Heights. Following the Israeli victory in the Six-Day War, Golda Meir's government came under enormous pressure to settle in all parts of the biblical Land of Israel. She responded with efforts to develop a small number of security-oriented settlements in Sinai, the Golan, and the Jordan Valley. The Jordan Valley settlements, the first in the West Bank, were conceived under the Allon Settlement Plan (adopted in 1974 but circulating since 1970) as agricultural settlements that would serve as outposts on Israel's Eastern front. Settlers, led by Gush Emunim leader Rabbi Moshe Levinger, also had early successes in manipulating the 
Labor government into supporting their extended stay in the Park Hotel in the city of Hebron, and eventually their establishment of Qiryat Arba on the outskirts of the city. ${ }^{6}$ Still, under the Eshkol, Meir, and Rabin governments there was not a great deal of civilian population transfer. By the time Menachem Begin and the Likud came to power in 1977, there were a total of 3200 settlers. ${ }^{7}$

As Begin biographers Ilan Peleg and Sasson Sofer have shown, Begin brought the religious right's Greater Israel theology, a territorial imperative, and a diplomacy of annexation into the political mainstream, thereby opening the gates of settlement. ${ }^{8}$ By the end of his second government as Prime Minister in 1983, the number of settlers had increased to $28,400 .{ }^{9}$ Moreover, Begin's second Defense Minister, Ariel Sharon, along with his Foreign Minister, Yitzhak Shamir, were to become the architects of a concerted expansion of the "facts on the ground." By contrast with the small amount of government support that West Bank civilian settlers received in the first decade after the Six-Day War, in recent years, they have received government mortgage and housing subsidies, tax incentives, business grants, free schooling, infrastructure projects, and defense- to the tune of about \$146 million in 2002. Since the Oslo Accords were signed in 1993, there has been a $55 \%$ growth in settlement housing and a 100\% growth in the settler population. Between 1994 and 1997, the Israeli Defense Forces (IDF) built 180 miles of bypass roads in the territories to protect settlers from sniping, bombing, and drive-by shootings..$^{10}$ The Military Commander has directed hundreds of thousands of gallons of aquifer water to settlements for household, agricultural, and landscaping needs. ${ }^{11}$

At first glance, international law seems quite plainly to prohibit all of these activities. No prohibition could seem more straightforward than the one found in the Fourth Geneva Convention, the one on protecting civilians in time of war, adopted on August I2, 1949. The Convention's Article 49, sixth paragraph, reads as follows: "The Occupying Power shall not ... transfer parts of its own civilian population into the territory it occupies." 12 The phrasing of this prohibition is absolute, permitting no exceptions. Israel ratified the Geneva Conventions on July 6, 1951. Moreover, by now, in the view of virtually all international lawyers and every state but Israel, the Geneva Conventions have become customary international law, meaning that every state is bound by them, whether it has formally become a Party to the treaties or not. From this standpoint, it makes no difference whether one is referring to Labor's security-oriented settlements of the I970s, the Likud-backed Gush Emunim settlements of the 1980s, Sharon's suburban dormitory settlements around Jerusalem and Tel-Aviv of the I99os, or the 
outposts of the new century. ${ }^{13}$ On the peshat reading of the Fourth Geneva Convention, they are all illegal.

The Article 49 prohibition is based on the so-called "law of belligerent occupation," a part of the traditional Law of Nations that was first published in 1907 in the Regulations to Hague Convention IV. The Israeli High Court of Justice recognizes the Hague Regulations as a binding part of customary international law. ${ }^{14}$ According to the Regulations, "Territory is considered occupied when it is actually placed under the authority of the hostile army." 15 That is, to be occupied, territory need not belong to any sovereign state; it need only be placed under the hostile army's effective control. A number of the Hague Regulations insist that occupation must have the character of a temporary trusteeship. For example, one Regulation specifies that the occupier is to respect and administer the laws already in force in the territory unless absolutely prevented from doing so. ${ }^{16}$ While all utilities may be seized, they "must be restored and compensation fixed when peace is made." ${ }^{77}$ The temporary nature of occupation is most explicit with regard to land use. In the words of Article 55, the Occupying Power "shall be regarded only as administrator ... of . . . real estate. . . It must safeguard the capital of these properties." 18

The implication is that the occupier administers the territory for the inhabitants while hostilities continue, but must return it to them more or less intact when peace has been concluded. The purpose of these provisions is to prevent occupiers from colonizing or annexing territory. The law of belligerent occupation aims to protect the territorial integrity of existing states, to discourage aggression, and to stabilize world order. While the Hague Regulations do not specifically mention an occupier's resettlement of its own civilians, such resettlement, if it appears as a means of $d e$ facto annexation or colonization of the occupied territory, cuts manifestly against their grain. ${ }^{19}$

During the half-century that followed the adoption of the Geneva Conventions, the law regarding occupant resettlement became ever more stringent. Since 1967, the US has voted in favor of ten Security Council resolutions that criticized Israel's failure to abide by the Fourth Geneva Convention, including Article 49, and demanded that Israel cease settlement activities and dismantle existing settlements. ${ }^{20}$ Most recently, the drafters of the 1998 Rome Statute, the treaty that established the International Criminal Court, classified resettlement as a war crime within the court's jurisdiction. ${ }^{21}$

Yet, while consistent and clear, international humanitarian norms have so far been largely unenforceable. While the Security Council resolutions 
clearly establish the international norm that the Fourth Convention applies to the settlements, the Council has so far never exercised its powers under chapters VI and VII of the UN Charter to enforce the norm. (This is not something President Bush calls attention to when criticizing the Council's track record on enforcement.) Moreover, for a number of reasons to be explored in a moment, the Rome Statute's reclassification of resettlement as a war crime is also unenforceable, and can have no practical effect on the situation in the territories right now. However, both sources of law do serve to indicate where the international law of war is heading on this issue.

In addition to being charged with violating the law of war, Israel's resettlement policy has been charged with numerous violations of international human rights law. The UN treaty bodies that monitor states' implementation of the International Bill of Rights, have determined that the West Bank and Gaza are under their jurisdiction, and that the settlements have resulted in Israel's violation of Palestinians' rights to self-determination, use of natural resources, equality, property, an adequate standard of living, and freedom of movement. ${ }^{22}$

\section{ISRAELI JURISPRUDENCE}

From a number of perspectives, international law has prohibited the Israeli settlements. Yet Israeli officials have generally ignored or dismissed international law and have relied instead on the opinions of Israeli jurists and legal theorists, who have treated this issue quite differently. ${ }^{23}$ Theoretically, according to the Vienna Convention on the Law of Treaties (entered into force, January 27, 1980), international law trumps national law when there is a conflict. ${ }^{24}$ Practically speaking, however, Israel has been able to observe this rule in the breach by refusing to sign the Vienna Convention. (This does not necessarily relieve Israel of the obligations of the Convention, if the treaty's provisions have been recognized as customary international law.) Two conditions have enabled Israeli national jurisprudence to prevail in regulating resettlement. The enforcement vacuum noted above has meant that Israel is under no compulsion to respond to international criticisms, as

long as it is willing to bear the political consequences for ignoring its treaty commitments. Second, the decades of manifest unfairness and politicization of the Israeli/Palestinian conflict in the Zionism=Racism resolution, condemnations by the Commission on Human Rights, UNESCO, and so on, have enabled Israeli officials to mischaracterize and dismiss all UN human rights bodies as anti-Zionist and anti-Semitic. 
It is therefore quite important to understand the extent to which Israeli legal theorists and jurists have differed in their approach from international norms. According to the 1968 "missing reversioner" theory advanced by Yehuda Z. Blum, Jordan's aggression against Israel in 1967 caused it to lose its title to the West Bank, creating a sovereignty vacuum that Israel stepped in to fill. In that case, the Fourth Convention would not apply because Israel had not occupied another state's sovereign territory, there was no sovereign to whom the territory could revert, and the settlements could not be in violation of the Convention. ${ }^{25}$ Besides, the Convention is designed for armed hostilities between states that are parties to the treaty (Fourth Convention, Art. 2); the territories do not comprise a state and therefore cannot be a party. ${ }^{26}$ Finally, the Israeli/Palestinian conflict does not fit into the Convention's definition of an "armed conflict not of an international character," because the conflict occurs in a non-state territory rather than "in the territory of one of the High Contracting Parties" (Art. 3). According to this argument, under the terms of the Convention, the Israeli/Palestinian struggle cannot be classified as either an international armed conflict or a non-international armed conflict, and these are the only conflicts covered by the Convention's definition of "occupied territory." Thus, Article 49's prohibition cannot be applied to the West Bank settlements.

With the rise of Menachem Begin, the Likud government took this theory further and claimed that, in the absence of a sovereign, Israel had in fact taken title to the territory, based on the Jews' ancient ancestral and biblical claim to the entire Land of Israel. Begin said, "You can annex foreign land. You cannot annex your own country. Judea and Sumaria are part of the land of Israel [Eretz Yisrael], where the nation was born." 27 This is a clear statement of Begin's policy of de facto annexation through settlement. ${ }^{28}$

The Israeli Foreign Ministry has also contributed a rationale for rejecting Israel's de jure obligation to uphold the Fourth Convention, arguing that the Convention only prohibits civilian transfers compelled by the government, not voluntary transfers undertaken by the civilians themselves. Recall the language of Article 49: "The Occupying Power shall not transfer its own civilians into the territory it occupies" (emphasis added). On the Foreign Minister's reading, even if the Geneva Convention applies, voluntary transfers do not violate it, because the Occupying Power is not doing the transfer. ${ }^{29}$

It is worth noting that the "Greater Israel" theory has been disputed by prominent Israeli legal authorities. Yoram Dinstein, a Professor of 
International Law at Tel-Aviv University and the editor of the Israel Yearbook on Human Rights, argued that the Fourth Convention "does not make its applicability conditional on recognition of titles" and that " $[t]$ he most basic tenet of the law of belligerent occupation is that occupation as such does not transfer title to the territory." 30 For Dinstein, the West Bank is a case of textbook belligerent occupation, and must be treated as such. A third theory, advanced by Moshe Drori and Thomas Kuttner, held that the territory was neither a sovereignty vacuum to be filled by Israel, nor a traditional occupied territory to be administered until the sovereign's return at the conclusion of diplomatic negotiations. Rather, the West Bank was being held by a "trustee-occupant," administering the area until the residents were ready to take over. Under this theory, Israel had become the new power exercising a mandate over the region, operating in the absence of a sovereign, aware of its temporary status, and aiding the inhabitants to become self-governing. As a trustee-occupant, the administration would still be based on the principles of occupation articulated in Art. 49. ${ }^{31}$

International law also takes issue with the various justifications of the settlement policy. On the first issue, the inapplicability of Geneva law to conflicts other than wars between states parties or those occurring on states parties' territory, international treaties and case law subsequent to the Geneva Conventions have sought to broaden the law of war to encompass armed conflicts between state and non-state entities. Both Protocol I, a treaty of 1977 , as well as a recent judgment from the International Criminal Tribunal for the former Yugoslavia (ICTY) assert that the laws of war can apply in armed conflicts between a state and a non-state entity. The ICTY judges assert that such conflicts must be treated as though they were interstate conflicts for the purpose of the application of Geneva law. ${ }^{32}$ Moreover, since Geneva law is accepted as customary everywhere but in Israel, ${ }^{33}$ the question of whether the territory is under the sovereign control of a High Contracting Party is no longer relevant. From this point of view, the prohibition of resettlement is applicable in the West Bank even though the Israeli-Palestinian crisis is an armed conflict between a state and a non-state entity occurring in a territory belonging to no state party.

On the issue of voluntary transfers, the Rome Statute disagrees with the Foreign Minister. The Statute classifies as a war crime, "The transfer, directly or indirectly, of parts of the Occupying Power's own civilian population into the territory it occupies" [emphasis added]. ${ }^{34}$ The drafters of the Rome Statute added the phrase "directly or indirectly" to the Fourth Convention language in order to reflect customary international law's prohibition against government encouragement of voluntary resettlement 
through subsidies, incentives, and defense. ${ }^{35}$ Such indirect means have, of course, been a part of Israeli government policy since the Allon Settlement Plan of 1970, and especially since the Drobles Plan of 1978, as revised by Likud governments in 1980 and $1983 .{ }^{36}$ So here, the Foreign Minister and international law are at odds.

For the most part, however, rather than arguing for the inapplicability of particular provisions in the Fourth Convention, the Israeli High Court of Justice has denied outright the Convention's jurisdiction over Israel's activities in the territories. ${ }^{37}$ In 1980, in a case brought by the Palestinian mayors of Hebron and Nablus who had been deported to Lebanon, the Court rejected the status of the Fourth Convention as customary international law and discounted its binding nature, claiming that the treaty "belongs to conventional international law [as opposed to customary international law], which does not form part of Israeli municipal law unless incorporated by legislation." 38 On the Court's reading, the Convention is non-self-executing, meaning that even though Israel ratified the treaty, the government is not bound to apply it unless the Knesset first passes a law to that effect. Again, Israeli and international law disagree: the U.N. Security Council has (with United States support) repeatedly asserted that the Fourth Convention is customary, applicable, and binding. ${ }^{39}$

The High Court's rejection of the applicability of the Geneva Convention and all later treaties relevant to civilian transfer has compelled it to rest its decisions regarding the settlements on the undisputed customary law of belligerent occupation as declared in the 1907 Hague Regulations. ${ }^{40}$ In the Regulations, the Israeli High Court has been able to find warrant for certain kinds of civilian resettlement in the territories. Article 43 of the Regulations permits the occupant to alter existing conditions when absolutely necessary to ensure "public order and safety." The High Court has interpreted the phrase "public order and safety" to mean the IDF can alter existing conditions in cases of "military need." This interpretation enabled the court, in the Beth El case of March 1979, ${ }^{41}$ to decide that "military need" justified the Military Commander in requisitioning privately-owned Palestinian land in the West Bank to be turned over to the civilian government for settlement construction. The Court wrote that "Jewish settlements in occupied territories serve actual and real security needs" inasmuch as civilian settlers can report suspicious activities of occupied inhabitants to the IDF. This decision seemed to establish the legal basis by which the Military Commander could requisition hundreds of thousands of acres of privately-owned Palestinian land for settlement construction. ${ }^{42}$ 
Yet only nine months later, the High Court issued a landmark decision in the Elon Moreh case-a case involving the IDF's requisition of privately held Palestinian land for a new Gush Emunim settlement in the West Bank. ${ }^{43}$ Here, the court used the condition of "military need" to rule against the Military Commander and find the requisition order null and void, determining that the new settlement was primarily motivated by political and religious concerns rather than military need. ${ }^{44}$ In Elon Moreh, the Court placed a limit on the kinds of settlements that could be justified as military needs. It said:

the decision to establish a permanent settlement intended from the outset to remain in its place forever-even beyond the duration of the military government which was established in Judea and Sumaria-encounters a legal obstacle which is insurmountable, because military government cannot create in its area facts for its military needs which are designed $a b$ initio [from the outset] to exist even after the end of the military rule in that area, when the fate of the area after the termination of military rule is still not known. ... ${ }^{45}$

So the court's interpretation of the Hague Regulations in Beth El and Elon Moreh enabled it to determine that some settlements were lawful- those serving military need and intended to be of only temporary durationwhile others were not. This approach was far different, of course, from the Fourth Convention and the Rome Statute, which simply prohibit resettlement altogether.

In the wake of Elon Moreh, the Begin government ceased to requisition private lands. Its new approach was to reclassify all unregistered lands in the West Bank as "state lands" unless individuals could come forward with title papers. Prior to 1967, the Ottoman and Jordanian law in force in the West Bank did not require title papers and registration; this meant that many Palestinians could not prove ownership of land their families had worked for generations. This strategy depended on a wholesale reinterpretation and invalidation of much of the existing law in force in the occupied territory, in violation of the Hague Regulations. Nevertheless, it resulted in the government claiming about $40 \%$ of the West Bank as state land, about 2,150,000 dunams (or about half a million acres). ${ }^{46}$ Since 1979, 90\% of all new settlements have been built on these state lands. ${ }^{47}$ By refusing to rule on the legality of settlement construction on state lands, the Israeli courts have embarked on a collision course with international law, since as we have 
seen, the Hague Regulations require the Occupying Power to refrain from substantial alterations to the real estate under its effective control.

The Court's reliance on the Hague Regulations has, in any case, resulted in a decision record that frequently differs from international norms. For one thing, when the court decided in Beth El that civilian settlers can serve military needs, it seemed to place settlers somewhere between civilians and combatants. Inasmuch as the civilian/combatant distinction is the fundamental basis for the international law of war, this decision was in conflict with that law.

In cases relating to the human rights of the settlers themselves, the High Court has also departed from the distinction in international law between occupied and occupier. In one case, the High Court found that even though Jewish settlers are Israeli citizens, they are under IDF administration, and, like Palestinian inhabitants of the West Bank, may be subject to detention without charge, trial, or counsel. ${ }^{48}$ From the standpoint of international human rights, which frowns upon administrative detention, the High Court's ruling appears to result in violation of the settlers' human rights. ${ }^{49}$ Here, the court treated settlers as though they were occupied rather than occupier.

Overall, the status of the settlers in Israeli jurisprudence has been quite fluid. In some cases the court treats them as occupant civilians, in others as occupied civilians, and in others as combatants. This fluidity in itself creates a conflict with the international law of war, because the latter seeks to provide a single, clearly defined status for each type of participant in armed hostilities. From the perspective of international law, the Israeli decisions have lacked any discernible philosophical foundation. On the other hand, from the Israeli High Court's perspective, the neat, consistent logic of the Geneva norms fails to address the messy conditions of actual armed conflict.

\section{CONTEXTUALIZING THE LAW}

The High Court's retort emphasizes the importance of contextualization in understanding and applying law in situations of armed conflict. Indeed, while law is the necessary basis for a comprehensive consideration of Israeli policy towards the settlements, it can never be sufficient. Other factors that would have to be incorporated include: 
- the historical development of Israeli policy toward the settlements

- the impact of the settlements on Israeli domestic politics

- their impact on the Israeli economy

- their impact on West Bank topography, land use, and administration

- their impact on the Israeli/Palestinian conflict, and on the broader Middle East conflict

- the relation between the settlements and the security barrier

- their impact on Israeli foreign relations, especially with the United Nations, the United States, and the European Union

- use of U.S. loan guarantees for purposes of settlement expansion

- water security issues

- border security issues

- the historical and ideological development of the various segments of the settler movement

- settlement and the ideologies of Zionism

- the development of Israeli human rights and refusenik movements

- settlers and settlements in Israeli popular culture and the arts

Three examples will illustrate the crucial role that context plays in the interpretation of the law. First, border security issues profoundly affect the application of the law of belligerent occupation to the settlements. According to UN Security Council Resolution 242 (June I4, 1967) Israel must return "territories" occupied during the Six-Day War. While Palestinian representatives have always held that this means Israel must return all territories captured, the Israeli government has always held that the absence of the definite article (the territories) means that Israel must return only some of the captured territories. On Israel's reading, the resolution recognizes that the Green Line is a cease-fire line rather than a permanent border, providing some small margin on either side of the line open to negotiation.

From this point of view, in a negotiated peace treaty, Israel's borders could be slightly expanded, and this expansion could have the effect of conferring lawfulness for the future on a number of settlements, even if such settlements had been established illegally. This was the solution unofficially reached by negotiators from both sides at the Clinton-brokered talks in Taba, Egypt in January 200r. ${ }^{50}$ In that understanding (reflected in the approach taken in the recent private initiative known as the Geneva Accord) the suburban dormitory settlements around Jerusalem, first built in the late 1980s and 1990s, are to be included in the permanent borders of Israel, in exchange for an equal amount of Israeli land ceded to the new state of Palestine. Thus, while the Fourth Geneva Convention makes all 
civilian resettlement unlawful, another legitimate source of international law, a Security Council Resolution, seems to permit a narrow exception when border security issues are in question.

While this security-based argument seems persuasive for some of the Jerusalem settlements, a similar argument will probably not hold up when applied to the other main line of settlements built along a border: the kibbutzim and moshavim built by Labor as security settlements along the Eastern edge of the West Bank under the Allon plan in the mid-r97os. Accepting that civilian settlers can serve security functions-and this is a debatable assertion, as we have seen-the question of whether the Allon settlements serve military need has always rested on the threat of attack from Jordan or Iraq. It is no longer clear that Israel faces the same level of threat from its Eastern front as it did in the I970s. Since Jordan and Israel have signed a Treaty of Peace, and moreover, have established partnerships and cooperation on a broad range of issues, the threat from Jordan seems remote. ${ }^{51}$ With the removal of Saddam Hussein from power, the statesponsored threat from Iraq no longer exists. Thus, the historical context that initially undergirded Labor's establishment of Allon settlements has been substantially transformed.

With regard to those settlements built in the interior of the West Bank under the Drobles Plan of 1977, with the support of Gush Emunim and the Begin and Shamir governments, and expanded by subsequent governments, we must resort to the contexts of geography and land use planning. Topographically, many of the Drobles settlements have been deliberately built along the mountain ranges overlooking Palestinian villages, giving the settlers a strategic and symbolic advantage. The settlements' topographical separation from the lowland villages has enabled Israeli planners to imagine the West Bank as a patchwork of discontinuous areas held together by raised road arteries. ${ }^{52}$ The Drobles settlements were placed not only above but geographically around the seven major Palestinian cities in the West Bank. The geographic placement coincided with the political aims articulated by Drobles, the World Zionist Organization, the Gush Emunim, and the Begin government: to encircle major Palestinian cities so as to prevent these cities from growing toward one another or forming a contiguous Palestinian state. The contexts of topography and land use planning help clarify that the mountain-based "encirclement settlements" represent precisely the sort of de facto colonization that the law of belligerent occupation prohibits.

Finally, the example of the security barrier that Israel has been building reveals the degree to which the settlements can have an effect on 
seemingly unrelated questions, and discloses yet another breach between Israeli and international jurisprudence. Both the Israeli High Court of Justice and the International Court of Justice, in recent opinions about the barrier, concur that the West Bank is under the law of belligerent occupation, exemplified by The Hague Regulations and the Fourth Geneva Convention. ${ }^{53}$ But then their opinions diverge.

According to the Israeli court's ruling on June 30, 2004, part of the barrier's route "undermines the delicate balance between the obligation of the military commander to preserve security and his obligation to provide for the needs of the local inhabitants." ${ }^{54}$ Chief Justice Aharon Barak ordered 19 miles of the barrier rerouted in order to address Palestinians' humanitarian concerns, but permitted Israel to continue building the barrier along a new route in consideration of Israel's right of self-defense against terrorism. ${ }^{55}$ In other words, the HCJ recognized the barrier as justifiable, agreeing with the Government that certain Palestinian rights (e.g., freedom of movement) are derogable due to severe threats to Israel's national security. It cautioned, however, that "The purpose of the separation fence cannot be to draw a political border," ${ }^{56}$ and that any route must be chosen strictly for security considerations. Where military need can be shown to be actually in question, the court does not object to routing the barrier into the interior of the West Bank.

On the other hand, according to the July 9, 2004 Advisory Opinion of the International Court of Justice, the barrier might be justified under Security Council Resolution 242 (1967) only if it hewed close to the Green Line. ${ }^{57}$ But the ICJ opinion finds that the barrier route does not remain on the Green Line but "It is essentially in these [occupied] territories that Israel has constructed or plans to construct" the barrier (para. 79). ${ }^{58}$ Also, the rationale that might be provided by Resolution 242 does not outweigh the barrier's contravention of other sources of international law. While agreeing that, under Art. 4 of the International Covenant on Civil and Political Rights, certain rights are derogable, the ICJ rejected the derogability of Palestinians' freedom of movement in this case. Moreover, it found that the barrier violated a number of other Palestinian rights, including the rights to work, health, education, and an adequate standard of living. ${ }^{59}$

It was the relation of the barrier to the settlements, however, to which the ICJ's opinion paid the most attention. The court argued that, because the barrier route was drawn to enclose "8o per cent of the settlers living in the Occupied Palestinian Territory, that is 320,000 individuals," 60 it was in danger of turning the illegal settlements into Israeli neighborhoods by a process of de facto annexation, thus depriving Palestinians of 16 per cent 
of their territory in the West Bank. Because 160,000 Palestinians would also be enclosed by the barrier in "almost completely encircled communities," ${ }^{61}$ their right to self-determination would also be violated. In other words, the barrier exceeds the negotiable margin permitted under 242 wherever the government extends it eastward into the interior of the West Bank. If the eastward portion is employed to defend civilians in any of the encirclement settlements, that portion becomes a prop of the resettlement effort. For these reasons, the ICJ opinion concludes that the barrier must be dismantled in its entirety. Here, then, is yet another area of conflict between the two legal regimes.

Even this brief analysis reveals that, if the law's prescriptions are to hold during situations of armed conflict, legal norms must be applied in the contexts that actually obtain. Already in the few cases mentioned, knowledge of the context indicates that in a negotiated, two-state solution, there might be justification for Israel's retention of a few settlements proximate to the Green Line, while most would have to be dismantled.

But while the law must be contextualized, it must nevertheless remain a primary consideration for anyone who seeks to understand the nuances of the settlement issue. The claims of international law cannot simply be dismissed as the products of anti-Zionism or anti-Semitism, or of a biased world order. The international law of war began to address the issue of civilian resettlement long before the Israeli occupation began. Since 1945, the law of occupation has largely developed independently of UN bodies (like the General Assembly and the Commission on Human Rights) that have demonstrated a pattern of gross and reliably attested bias towards Israel. Moreover, a key means by which Israel can resist the attempts of its enemies to isolate it as a pariah state is by upholding the norms of treaties to which it has bound itself. No one wants to imitate the Commission on Human Rights by holding Israel to a higher standard than other states; but on the other hand, Israel's supporters should not seek to hold it to a lower standard, either. Finally, Israeli policymakers ignore the law at their peril, since it is the interaction of legal norms with sociopolitical realities that will ultimately determine the fate of the settlements.

\section{THE INTERNATIONAL CRIMINAL COURT}

Assuming policymakers wish to adhere to the law regarding the settlements, to which law should they adhere? ${ }^{62}$ As we have seen, the tension between international and Israeli law has been very high. So far, 
international law's relatively weak enforcement mechanisms have permitted lawmakers to rely on Israel's internal jurisprudence. Yet this state of affairs may be in transition, due to the establishment of the International Criminal Court in 2002. At the moment, the ICC cannot prosecute Israeli officials and military commanders for the war crime of resettlement. While the UN Security Council has the authority to refer a situation taking place anywhere in the world to the new Court, Israelis are protected from such a referral by the United States' veto power. Other potential plaintiffs may lodge a complaint only if either Israel or the Palestinian Authority has ratified the Rome Statute. But Israel will not ratify it, and the PA cannot do so, having no treaty-making power. ${ }^{63}$ So Israelis are apparently immune from these plaintiffs as well.

Under a number of different scenarios, however, the Court may yet gain jurisdiction over a case. To take only the most obvious possibility: the United States could decide to abstain on or vote in favor of a Security Council referral to the ICC. Considering the Bush Administration's recent declaration of support for making some settlements permanent, this scenario is unlikely to materialize any time soon. Yet given the consistent position taken by U.S. governments in Security Council resolutions for a quarter of a century, it is at least possible that a future American administration will find it in its interest to placate world and Arab opinion by permitting an ICC inquiry into Israel's resettlement activities to go forward.

We are left to ponder what the broader consequences might be, if an Israeli high official were tried and convicted by the international court as a war criminal. Some possibilities include the heightening of hostilities and the weakening of Israel's negotiating posture; the renegotiation of the US-Israel alliance; international ostracism the like of which even Israel has never seen; and, as the trial was played out on Israeli television, internal strife that could range anywhere from increasing factionalism to serious civil disturbances. And on top of all this, there would be the shame and anger of knowing that an international court had branded an Israeli national as one of the world's worst criminals.

\section{Notes}

My thanks to Georgia State University for the professional leave and grant support that made this research possible, and to Prof. Johan van der Vyver of the Emory University School of Law, from whom I acquired necessary concepts and tools. 
I. UNGAR 3379 (XXX): Elimination of all forms of racial discrimination $-2400^{\text {th }}$ plenary meeting determines that Zionism is a form of racism and racial discrimination (New York, Io November 1975); Asian Preparatory Meeting, UN World Conference against Racism, Racial Discrimination, Xenophobia and Related Intolerance (WCAR), Declaration and Plan of Action (Tehran, Islamic Republic of Iran, I9-2I February 200I).

2. The UN Commission on Human Rights (CHR) - a body comprised of the delegates of UN member states and thus overtly political-has dealt harshly with Israel from just after the Six-Day War. In I970, Israel was only the second country (after Pinochet's Chile) to be investigated under the Commission's secret Resolution $\mathrm{I} 503$ procedure. In recent years, the public condemnations have become an annual ritual. One month after the start of the second intifada in September 2000, CHR held only its fifth "special session” to condemn Israel for "Grave and massive violations of the human rights of the Palestinian people by Israel” (Geneva, I7-I9 October 2000) UN Doc. E/CN.4/RES/S-5/I. Also see UN Economic and Social Council, "Report of the Commission on Human Rights on its fifth Special Session" (Geneva, 9 November 2000) E/2000/II2. Since then, the CHR has adopted the following resolutions condemning Israel (more than for any other country): from the $57^{\text {th }}$ session, "Situation in occupied Palestine" (Geneva, 6 April 20oI) UN Doc. E/CN.4/RES/200I/2; "Human Rights in the occupied Syrian Golan” (Geneva, I8 April 200I) UN Doc. E/CN.4/RES/20oI/6; "Question of the violation of human rights in the occupied Arab territories, including Palestine" (Geneva, I8 April 200I) UN Doc. E/CN.4/RES/200I/7; "Israeli settlements in the occupied Arab territories" (Geneva, I8 April 200I) UN Doc. E/CN.4/RES/20oI/8. In its $58^{\text {th }}$ session, CHR adopted these resolutions: "Situation of human rights in the occupied Palestinian territory" (Geneva, 5 April 2002) UN Doc E/CN.4/RES/2002/I; "Situation in occupied Palestine" (Geneva, I2 April 2002) UN Doc. E/CN.4/RES/2002/3; "Human Rights in the occupied Syrian Golan” (Geneva, I2 April 2002) UN Doc. E/CN.4/RES/2002/6; "Israeli settlements in the occupied Arab territories" (Geneva, I2 April 2002) UN Doc. E/CN.4/RES/2002/7; "Question of the violation of human rights in the occupied Arab territories, including Palestine" (Geneva, I5 April 2002) UN Doc. E/CN.4/RES/2002/8; "Human rights situation of Lebanese Detainees in Israel” (Geneva, I9 April 2002) UN Doc. E/CN.4/RES/2002/IO; "The situation of human rights in the occupied Palestinian territory" (Geneva, 26 April 2002) UN Doc. E/CN.4/RES/2002/90. In its $59^{\text {th }}$ session, CHR adopted the following resolutions: "Situation in occupied Palestine" (Geneva, I4 April 2003) UN Doc. E/CN.4/RES/2003/3; "Human rights in the occupied Syrian Golan" (Geneva, I5 April 2003) UN Doc. E/CN.4/RES/2003/5; "Question of the violation of human rights in the occupied Arab territories, including Palestine" (Geneva, I5 April 2003) UN Doc. E/CN.4/RES/2003/6; "Israeli settlements in the occupied Arab territories" (Geneva, I5 April 2003) UN Doc. E/CN.4/RES/2003/7; "Human rights situation of the Lebanese detainees in Israel" (Geneva, I6 April 2003) UN Doc. E/CN.4/RES/2003/8. In addition, since 1993, Israel has been the subject of 
annual reports by John Dugard, the Special Rapporteur of the Commission on Human Rights on "the situation of human rights in the Palestinian territories occupied since 1967." Israel has been investigated by CHR's thematic mechanisms, including working groups or special rapporteurs on torture, arbitrary detention, and extrajudicial and summary executions. On the website of the Office of the High Commissioner for Human Rights, Palestinian human rights are the only specific situation mentioned in CHR's "Main Themes" (http://www.ohchr.org/ english/bodies/chr/intro.htm).

3. See Dov Shefi, "The Protection of Human Rights in Areas Administered by Israel: UN Findings and Reality," Israel Yearbook on Human Rights, 3, I973, 337-6I; Irwin Cotler, "Jewish NGOs and Religious Human Rights: A Case Study," in Michael J. Broyde and John Witte, Jr. (eds), Human Rights in Judaism: Cultural, Religious, and Political Perspectives, (Northvale, NJ, 1998), 245-52; Natan Lerner, The U.N. Convention on the Elimination of all Forms of Racial Discrimination (Rockville, MD, I980); Jerome J. Shestack, "Human-Rights Issues in Israel's Rule of the West Bank and Gaza," in David Sidorsky (ed), with Sidney Liskofsky and Jerome J. Shestack, Essays on Human Rights: Contemporary Issues and Jewish Perspectives (Philadelphia, 1979), 193-209; and Daniel P. Moynihan, "The Significance of the Zionism-as-Racism Resolution for International Human Rights," in Essays on Human Rights, 37-45.

4. For accounts of Jewish human rights activism in the early decades of the UN, see Cotler, Jewish NGOs and Religions Human Rights, 165-87; Felice Gaer, "Reality Check: Human Rights NGOs Confront Governments at the UN," in Thomas G. Weiss and Leon Gordenker (eds), NGOs, the UN, and Global Governance (Boulder, 1996), 5I-66; William Korey, NGOs and the Universal Declaration of Human Rights: A Curious Grapevine (New York, 1998), 2I-88; Nehemiah Robinson, The United Nations and the World Jewish Congress (London, 1956), I-I2O; Moses Moskowitz, Human Rights and World Order (Dobbs Ferry, NY, 1958), II3-44 and Forward; and Raphael Lemkin, Axis Rule in Occupied Europe (Washington, 1944) passim.

5. American Jewish Committee, "Fact Sheet on Israeli Settlements" [unpublished brief] (New York, July 25, 2003), 2-3.

6. For a history of early settlement, see Yehiel Admnoi, Decade of Discretion: Settlement Beyond the Green Line, 1967-I977 (Tel-Aviv, 1992) [Hebrew] passim; Ilan Peleg, Human Rights in the West Bank and Gaza: Legacy and Politics (Syracuse, NY, 1995), 22-43.

7. Ilan Peleg, "The Legacy of Begin and Beginism for the Israeli Political System," in Gregory S. Mahler (ed), Israel after Begin (Albany, 1990), 19-49; Peleg, Human Rights, 22-5.

8. Peleg, Human Rights, and Begin's Foreign Policy, I977-1983: Israel's Move to the Right (Westport, CT, 1987), 5I-I42; Sasson Sofer, Begin: An Anatomy of Leadership (New York, 1988), I24-66; Arye Naor, Greater Israel: Theology and Policy] (Haifa, 200I) passim. [Hebrew].

9. Peleg, "The Legacy," 3 I. 
Io. American Jewish Committee, "Fact Sheet," 3; Geoffrey Aronson, Settlements and the Israel-Palestinian Negotiations: An Overview (Washington, DC, 1996), I4-16; Laurie Copans, "Jewish settlers granted US \$34 million in tax breaks, government report says," Associated Press (New York, 6 November 2002); Editorial, "Chance for Change in Israel," New York Times (New York, 3r October 2002), A26.

II. For the controversy surrounding water use in the settlements, see, e.g., UN ECOSOC Res. 1990/53, July 24, 1990; Yehezkel Lein, Land Grab: Israel's Settlement Policy in the West Bank (Jerusalem, May 2002), 95.

I2. See page 318 in Adam Roberts and Richard Guelff (eds), Documents on the Laws of War, 3rd ed. (New York, 2000) for the 1949 Geneva Convention IV Relative to the Protection of Civilian Persons in Time of War, Art. 49.

13. For a history of the religious wing of the settlement movement, see Amnon Rubinstein, From Herzl to Rabin: The Changing Image of Zionism (New York, 2000), III-I58; Robert I. Friedman, Zealots for Zion: Inside Israel's West Bank Settlement Movement (New Brunswick, NJ, 1992) passim; Peleg, Human Rights, 35-43.

I4. For the court's recent affirmation of the applicability of The Hague Regulations and the law of "belligerent occupation" to the West Bank, see Beit Sourik Village Council v. The Government of Israel, HCJ 2056/04, June 30, 2004.

I5. Hague Convention IV Respecting the Laws and Customs of War on Land, Annex to the Convention, Regulations Respecting the Laws and Customs of War on Land [a.k.a. "The Hague Regulations"] (The Hague, 1907) Art. 42.

16. The Hague Regulations (The Hague, 1907) Art. 43.

17. Ibid., Art. 53; also see Art. 54.

I8. Ibid., Art. 55.

19. See David Kretzmer, The Occupation of Justice: The Supreme Court of Israel and the Occupied Territories (Albany, 2002), 2I-5, 34-40, 43-56. He suggests (75) that the civilian settlements in the territories have "made the regime there much closer to a colonial regime than one of belligerent occupation."

20. U.S. voting history in the UNSC on the settlements goes back to just after the Six-Day War. The U.S. voted in favor of UN Security Council Official Records (UNSCOR) 237 (New York, June I4, 1967). It abstained on UNSCOR 446 (New York, 1979) and 452 (New York, 1979) both of which called the settlements a violation of international law and calling for their dismantlement and cessation. The U.S. voted in favor of UNSCOR 465 (New York, 1980) which called Israeli settlement activity "a flagrant violation of the Geneva Convention" and demanded that Israel dismantle the settlements. In the years following the first intifada, the US voted in favor of UNSCOR 607 (New York, 1988); 672 (New York, 1990); 673 (New York, 1990); 68I (New York, I990); 694 (New York, 199I); 726 (New York, 1992); 799 (New York, 1992); and I435 (New York, 2002) calling for Israel to meet its Fourth Convention obligations and/or cease settlement activity. It also abstained on or voted in favor of countless UNGA resolutions to the same effect. For a listing of such resolutions from 1967-92, see Jody Boudreault, 
Emma Naughton, and Yasser Salaam (eds), U.S. Official Statements: Israeli Settlements, the Fourth Geneva Convention (Washington, D.C., I992) app. C, "Listing of UN Security Council \& General Assembly Resolutions Regarding Israeli Settlements for which the U.S. Voted 'In Favor' or 'Abstain'," I8I; and app. E, "Listing of UN Security Council \& General Assembly Resolutions Mentioning the Fourth Geneva Convention for which the U.S. Voted 'In Favor' or 'Abstain'," I90-3. See the UN's own listing at http://www.un.org/Docs/sc/unsc_resolutions.html.

2I. Rome Statute of the International Criminal Court, Art. 8(2)(b)(viii) (Rome, I998).

22. See the concluding comments of the Committee on Economic, Social, and Cultural Rights, I9 ${ }^{\text {th }}$ Session, E/C.I2/IAdd.27 and the Committee on Human Rights, $63^{\text {rd }}$ session (Geneva, 1998), CCPR/C/79/Add93; Lein, Land Grab, 4I-5.

23. The Israel Year Book on Human Rights (Tel-Aviv, I97I-present) has made much of the Israeli legal discussion available for English readers, as will become apparent below.

24. Vienna Convention on the Law of Treaties (Vienna, 1980) Art. 27: "A party may not invoke the provisions of its internal law as justification for its failure to perform a treaty."

25. See Yehuda Blum, "The Missing Reversioner: Reflections on the Status of Judea and Sumaria," Israel Law Review, 3, I968, 279; Meir Shamgar, "The Observance of International Law in the Administered Territories," IYHR, 3, I97I, 262-77; Arie Pach, "Human Rights in West Bank Military Courts," IYHR, 7, I977, 229, 252.

26. Shamgar, "The Observance of International Law in the Administered Territories," 262-77.

27. Quoted in John Quigley, "Loan Guarantees Israeli Settlements, and Middle East Peace," Vanderbilt J. of Transnational Law, 25 November 1992, 56I.

28. For a legal analysis of Begin's position, see Theodor Meron, "West Bank and Gaza: Human Rights and Humanitarian Law in the Period of Transition," IYHR, 9, 1979, I06-20.

29. Israeli Ministry of Foreign Affairs, Israeli Settlements-Their Conformity with International Law (Jerusalem, December 1996), www.israel-mfa.gov.il; see also Yoram Dinstein, "The International Law of Belligerent Occupation and Human Rights," IYHR, 8, 1978, I04-43.

30. Yoram Dinstein, "The International Law of Belligerent Occupation and Human Rights," I07, I05; Dinstein, "The Israel Supreme Court and the Law of Belligerent Occupation: Article 43 of the Hague Regulations," IYHR, 25, I995, I-20; Dinstein, "The International Legal Status of the West Bank and the Gaza Strip-I998," IYRH, 28, 1998, 37-49; Kretzmer, The Occupation of Justice, 2I-40.

3I. Moshe Drori, "The Legal System in Judea and Sumaria: A Review of the Previous Decade with a Glance at the Future," IYHR, 8, 1978, I44-77; Thomas S. Kuttner, "Israel and the West Bank: Aspects of the Law of Belligerent Occupation," IYHR, 7, 1977, I66-22I. 
32. See 1977 Geneva Protocol I Additional to the Geneva Conventions of I2 August 1949, and Relating to the Protection of Victims of International Armed Conflicts, Arts. I(4), 50, 85(4)(a), 85(5); and Prosecutor v. Zejnil Delalic et al. ("The Celebici Case"), Judgment of Appeals Chamber, International Criminal Tribunal for the former Yugoslavia (The Hague, 1998) paras. 96-IOI.

33. The Geneva Conventions' customary status is indicated both by their adoption by every UN member state and by states' parties explicit statements that the Conventions are binding on all conflicts including the conflict in the Israeli occupied territories. See International Committee of the Red Cross, "States party to the Geneva Conventions and their Additional Protocols: Geneva Conventions of I2 August 1949 and Add. Protocols of 8 June 1977," updated as of I June 2004. http://www.icrc.org/Web/Eng/siteengo.nsf/iwpListıo3/ $77 \mathrm{EAsBDEE}_{20} \mathrm{~B}_{4} \mathrm{CCDC}$ 1256B6600595596. For an explicit statement that the Fourth Convention is binding in the territories, see the "Statement" issued at the Conference of the High Contracting Parties of the Fourth Geneva Convention (Geneva, Is July 1999). Only the United States and Israel voted against the "Statement."

34. Rome Statute of the International Criminal Court, Art. 8(2)(b)(viii) (Rome, 1998).

35. See Preparatory Commission for the International Criminal Court, "Proposals in relation to elements of article 8, paragraph 2 (b) (viii) of the Rome Statute of the International Criminal Court," Second Session (New York, 26 July-13 August, 1999) PCNICC/1999/WGEC/INF.3.

36. Meron Benvenisti, The West Bank Data Project: A Survey of Israel's Policies (Washington, 1984), 49-63; John Quigley, "Loan Guarantees, Israeli Settlements and Middle East Peace," Vanderbilt J. of Transnational Law, 25, November 1992, 560-8; American Jewish Committee, "Fact Sheet on Israeli Settlements," Io.

37. Kretzmer, The Occupation of Justice, 4I. The distinction is drawn between de facto observance of humanitarian protocols, and the de jure obligation to do so.

38. HC 698/80, Kawasme et al. v. Minister of Defence et al., cited in IYHR, II, 198I, 350-I; HC 785/87, Abd el Afu et al. v. The Commander of the IDF Forces in the West Bank et al., cited in $I Y H R, 23,1993,28 \mathrm{I}-2$.

39. See note 20.

40. Dinstein, "The Israel Supreme Court and the Law of Belligerent Occupation," I-2O.

4I. HC 606/78, Ayub et al. v. Minister of Defence et al. (the Beth El Case).

42. In a later case, Tabeeb v. Minister of Defense (198I) in $I Y H R$, 13, 1983, 364, the High Court sanctioned expropriation of privately held lands in the territories for highway construction.

43. For a description of the Israeli socio-political milieu precipitated by the Elon Moreh Case, see Geoffrey Aronson, Israel, Palestinians, and the Intifada: Creating Facts on the West Bank (New York and Wash., D.C., 1990), 93-116. 
44. H.C. 390/79, Mustafa Dweikat et al. v. the Government of Israel et al. (the Elon Moreh Case), in IYHR, 9, 1979, 350.

45. Ibid.

46. For a discussion of the Jordanian/Ottoman law of land acquisition and land use (mawat, miri, and matruke), see Peleg, Human Rights, 30-3; Lein, Land Grab, 5I.

47. See Kretzmer, The Occupation of Justice, 89-84.

48. Administrative Detention Appeal, 4/94, Ben-Horin v. The State of Israel, $I Y H R$, 30, 2000, 318-22.

49. Prohibition of administrative detention is integral to the international bill of human rights. See the Universal Declaration of Human Rights, Art. 9; International Covenant on Civil and Political Rights, Art. 9. Israel signed the ICCPR on December 19, 1966, and ratified it on October 3, I99I.

50. Israeli-Palestinian Joint Statement, Taba, Egypt, Jan. 27, 200I; Ambassador Miguel Moratinos, EU Special Representative to the Middle East Process, (EU non-paper), "EU description of the outcome of permanent status talks at Taba," Ha'aretz February I4, 2002.

5I. Jordanian-Israeli Treaty of Peace (Wadi 'Araba, 1994) in State of Israel, Ministry of Foreign Affairs, Peace between The State of Israel and the Hashemite Kingdom of Jordan (Jerusalem, 1994).

52. See Eyal Weizman, "The Politics of Verticality," openDemocracy Ltd., www.opendemocracy.net/debates/, posted on 24 April, 2002.

53. HC 2056/04, Beit Sourik Village Council v. The Government of Israel, June 30, 2004, para. 23. The Israeli court continues to reject Israel's de jure obligation under the Fourth Convention, but asserts that Israel adheres to the treaty's "humanitarian provisions."

54. Ibid., para. 60; BBC News, "Israel Court Orders Barrier Shift," http:// news.bbc.co.uk/go/pr/fr/-/I/hi/world/middle_east $/ 3852385$.stm, posted on June 30, 2004.

55. Beit Sourik Village Council v. The Government of Israel, paras. 28-30.

56. Ibid., para. 27.

57. International Court of Justice, "Legal Consequences of the Construction of a Wall in the Occupied Palestinian Territory," Advisory Opinion, General List No. 13I (The Hague, 9 July 2004) paras. 74 ff., para. II7.

58. Ibid., para. 79.

59. Ibid., paras. II9-22, I34. The barrier may also constitute a form of collective punishment in contravention of non-derogable humanitarian law (Hague Regulations, Art. 5o; Geneva Convention IV, Art. 33; Protocol I, Art. 2(d); Protocol II, Art. 4(I)(b). In the words of the Hague Regulations, "No general penalty, pecuniary or otherwise, shall be inflicted upon the [occupied] population on account of the acts of individuals for which they can not be regarded as jointly and severally responsible." On this point, see also Peleg, Human Rights in the West Bank and Gaza, I9. 
6o. International Court of Justice, "Legal Consequences," para. I22.

6I. Ibid., para. I22.

62. Whether policymakers wish to adhere to the law is debatable. See Ehud Sprinzak, "Illegalism in Israeli Political Culture: Theoretical and Historical Footnotes to the Pollard Affair and the Shin Beth Cover-Up," in Mahler (ed), Israel After Begin, 5I-69.

63. See the Rome Statute (Rome, 1998) Art. I2-15; the limits on the PA's treaty-making power are spelled out in the Declaration of Principles on Interim Self-Government Arrangements (the "Oslo Accords") (Wash. D.C., 1993); other relevant treaties include the Agreement on the Gaza Strip and the Jericho Area (Cairo, 1994); the Interim Agreement on the West Bank and the Gaza Strip (Wash., D.C., 1995); the Protocol Concerning Redeployment in Hebron (Jerusalem, 1997); and the Wye River Memorandum (Wash., D.C., 1998). 
Copyright of Israel Studies is the property of Indiana University Press and its content may not be copied or emailed to multiple sites or posted to a listserv without the copyright holder's express written permission. However, users may print, download, or email articles for individual use. 